DOI: https:// 10.15407/kvt195.01.023

UDC 004.94, 378.147.88

SUKHORUCHKINA O.N., Senior Researcher, Department of System Information Technologies e-mail: sukhoru@irtc.org.ua

PROGONNYI N.V., Researcher,

Department of System Information Technologies

e-mail: progonny@gmail.com

International Research and Training Center

for Information Technologies and Systems

of the National Academy of Sciences of Ukraine

and Ministry of Education and Science of Ukraine

Acad. Glushkov av., 40, Kiev, 03187, Ukraine

\title{
THE INFORMATION TECHNOLOGY FOR REMOTE AND VIRTUAL PRACTICAL RESEARCHES ON ROBOTICS
}

Introduction. The problem of timely updating of laboratory means for research and training in robotics and intelligent technologies is considered. The information technology is proposed for organization of the laboratory complex with two types of components - remotely controlled robotics equipment and virtual means for corresponding practical research. Today, such approaches are the most optimal for providing research and training processes with modern resources for acquiring practical experience in rapidly developing scientific fields.

The purpose of the article is to consider the information technology capabilities in the organization of remote access to physical equipment and virtual means for practical research and training on robotics.

Methods. Methods of distributed information and computing processes, communication protocols, and web application programming are used.

Results. Two types of specialized means of our laboratory complex - physical equipment with remote access and virtual environments are considered. The general structures of autonomous mobile robot and sensor module that can be used remotely for certain research and practical training are presented. Some examples of web applications that are intended to familiarize students with certain types of robotics systems by their $3 D$ models and to perform corresponding practical tasks with the automatic results checking are shown.

Conclusion. The use of the laboratory complex components according to the created technology leads to timely expansion of the resources for the state-of-the-art research and practical training on robotics or intelligent technologies by the students of many Ukraine technical universities.

Keywords: robotics, remote control technology, virtual laboratory, web applications. 


\section{INTRODUCTION}

The high rate of the progress in the intelligent technologies and robotics puts the corresponding requirements for the educational processes of training specialists in this area.

However, existing equipment for practical training and research is insufficient and limits introducing and deepening new disciplines or additional sections to already approved training programs in technical universities of Ukraine. The current state of educational technologies in this area of knowledge requires the active search for new realizations of the virtual laboratories and the development of appropriate software and hardware tools which can be shared by scientific and educational institutions.

Let us note that the term "virtual laboratory" can be used in various meanings. For example in [1] resource sharing of a physical equipment in remote mode is considered as a virtual laboratory. Following [2-5] we will consider two types of software and hardware systems - physical equipment with remote access (remote laboratory resources) and software that allows simulating laboratory experiments - virtual laboratory resources.

Modern robotic developments combine theoretical knowledge and practical achievements of many scientific disciplines. But the main task of robotics today is to increase the mobile robot autonomous abilities to perform complex tasks in a nondeterministic dynamic environment. Intelligent technologies have a particularly important role, providing perception, analysis and semantic interpretation of information about a mobile robot environment and making decisions for sensible actions of a technical system. Therefore, integrated disciplines on intelligent information technologies and robotics meet the current labor market needs, and it is extremely necessary to create conditions for use of modern laboratory complexes in educational processes and scientific research, in particular, remotely.

We have created specialized hardware and software components of laboratory complex consisting of the web simulator, physical remote controlled equipment and appropriate information technology for use of these components. The technique for the practical application of the virtual environment for some research in the simulator mode of certain physical modules and information processes that accompany the operation of complex dynamic objects, namely, mobile robots and manipulators are developed.

The purpose of the article is to consider the information technology capabilities in the organization of remote access to physical equipment and virtual means for practical research and training sessions on robotics. Hardware and software laboratory resources and corresponding techniques developed at the International Center are presented.

\section{FUNCTIONALITY OF LABORATORY COMPLEX EQUIPMENT}

Innovative research and training technique in robotics and intelligent technologies put forward certain functional requirements for laboratory complex components, first of all, the ability to control remotely certain modes of the physical components operation and receive the specified information in the given format, as well as using the resources of the virtual web simulator of some processes. 
Previously in the International Center the prototype of multifunctional autonomous in-door mobile robot (MR) and unified sensor module (SM) - the device with changeable sensors for perceptions environment properties were created as a result of scientific and technical projects. These original hardwaresoftware systems can be used as basic physical components of the laboratory complex for research or training experiments directly in the room where equipment is located or in the remote mode.

The mechatronic part of our MR is based on the robotic kit by Evolution Robotics (USA). The mobile platform is equipped by web-camera and a simple gripper with two-fingers. The CAN (Controller Area Network) network with microcontroller nodes was developed for various sensors signal processing, communications and power supply. For our MR budget models sensors are used: safety movement sensors, infrared rangefinders, temperature and illumination sensors, microphones.

The multifunction autonomous MR is the distributed system of interacting software and computing modules with corresponding communication resources, software and hardware effectors and modules for perception, analysis and taskoriented interpretation of the information about surroundings objects (Fig. 1, a). The MR autonomous functioning at dynamic environment is supported by original techniques of a two-modules intelligent control system (CS) with developed human-machine interface and distributed software (Fig. 1, b) [6, 7].

The computer $3 \mathrm{D}$ modelling is used for the MR control system and the graphic user interface at the same time. This technique provides a user with the dynamically synthesized models of the MR and environment. Now the repertoire of our MR has the following missions for autonomous operation:

- self-localization by the artificial visual landmarks;

- navigation to a predetermined position or to a specified object with replanning trajectory in the dynamic environment;

- monitoring the surrounding situation or supervise the specific objects in-door;

- pursuit of the moving target object;

- search, taking and moving target objects, etc.

All resources of MR control and obtaining necessary information are available to the remote user via Internet browser. The Fig. 2 shows the example of MR web interface screenshot after the robot completes the mission "Come to the object "Ukraine poster"".

The concept "run the mission" implies that the software of MR control system contains the program components for all MR actions that may be required for the autonomous achievement of the robot target state specified by the user as the mission parameters.

During the remote control sessions, the robot user can observe all functionally important state variables of the technical system, namely:

- current MR position coordinates;

- current measurement values of all its sensors;

- video images from the onboard camera;

3D models of MR operation environment and model of how the video camera perceives the environment model. 


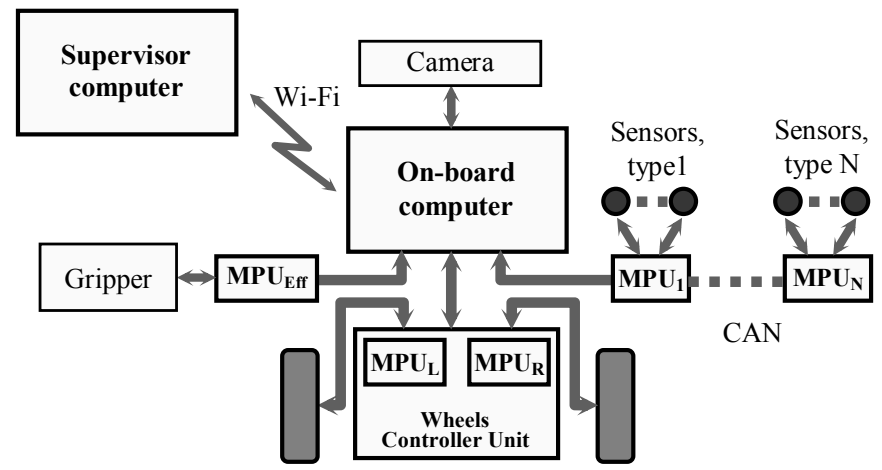

a)

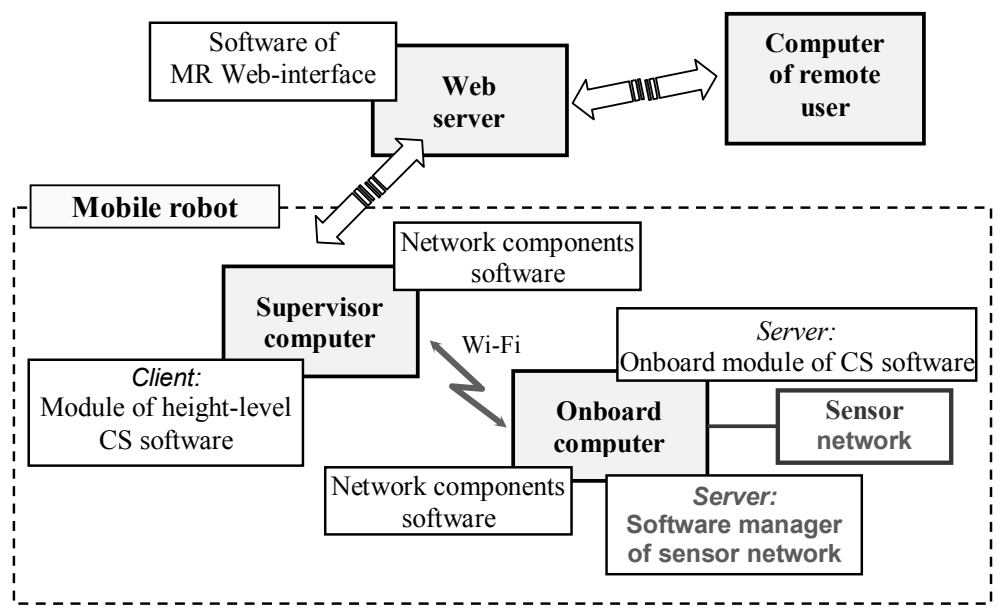

b)

Fig. 1. General MR hardware scheme (a) and distributed software modules of MR CS (b)

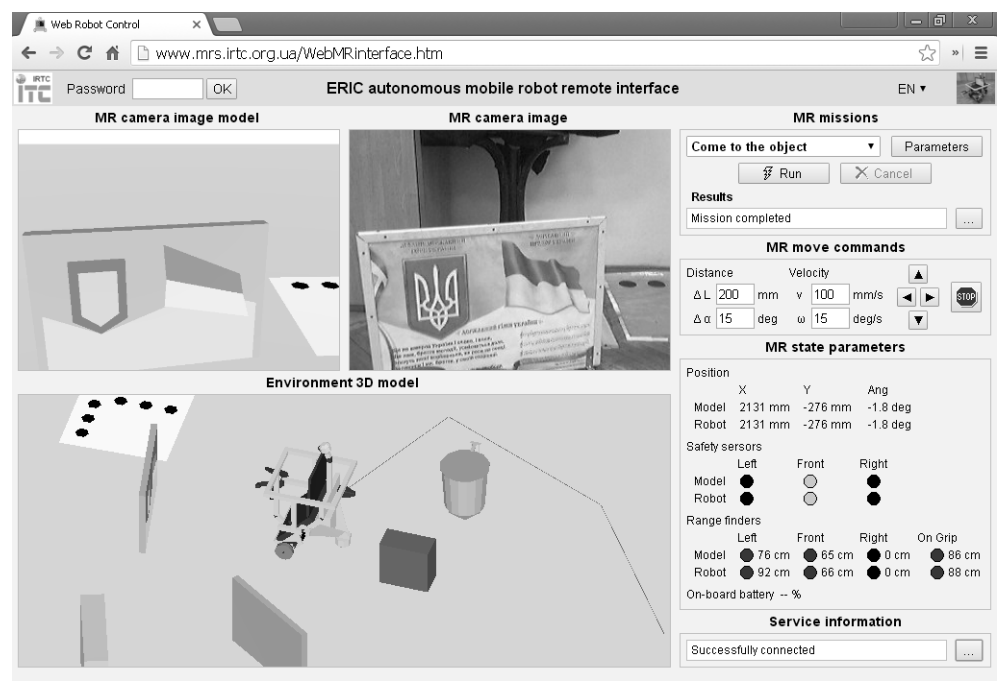

Fig. 2. MR web interface screenshot 


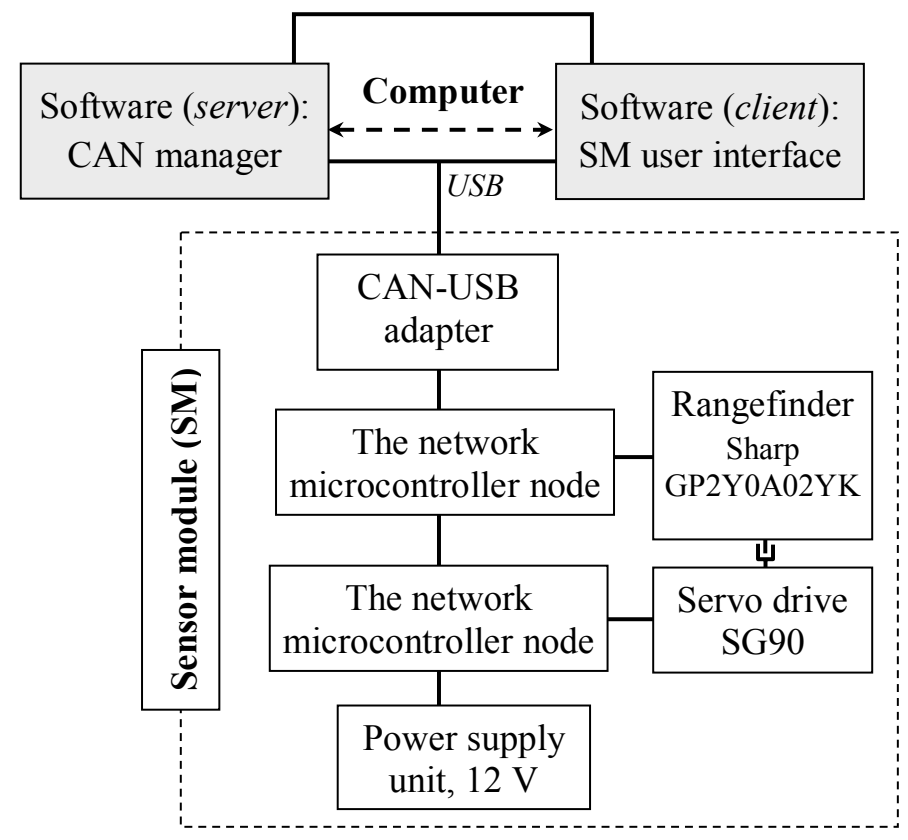

Fig. 3. SM device structure

In addition, the voice messages about MR current actions are synthesized.

There is a special set of missions when the robot performs specific actions, that generate a definite type of information, analysis and interpretation of which is the purpose of independent research with training purposes.

For example, rangefinder data are collecting and sending to the end user while MR autonomously moves around the target object. This information can be used as input for such tasks as data processing and approximation for compact description of the object contour [8].

On-line obtaining real sensory data from moving MR is important for the researcher to understand the specifics of the environment perception by technical means, and observe the random nature of the signal noise or signal delay, redundancy or uncertainty of such type information.

Another functional equipment of laboratory complex — unified SM. This device can also be used to collect sensory data about environment characteristics. The SM components and structure are shown in Fig. 3. In this example the sensor rangefinder is installed on the servo drive axis.

The general scheme of target object scanning process is shown in Fig. 4. The fixed coordinate system (CS) $O X Y Z$ is associated with a horizontal plane, where the SM and target objects for examination are located. The CS $O_{\mathrm{Rf}} X_{\mathrm{Rf}} Y_{\mathrm{Rf}} Z_{\mathrm{Rf}}$ is associated with the $\mathrm{SM}$ case. The axis $O Z$ coincides with the axis $O_{\mathrm{Rf}} Z_{\mathrm{Rf}}$ and with the axis of the servo drive. The position of the central axis of the sensing zone of the sensor forms with the axis $O X$ of the stationary $\mathrm{SC}$ the angle which changes during the rotational movement of the sensor. 


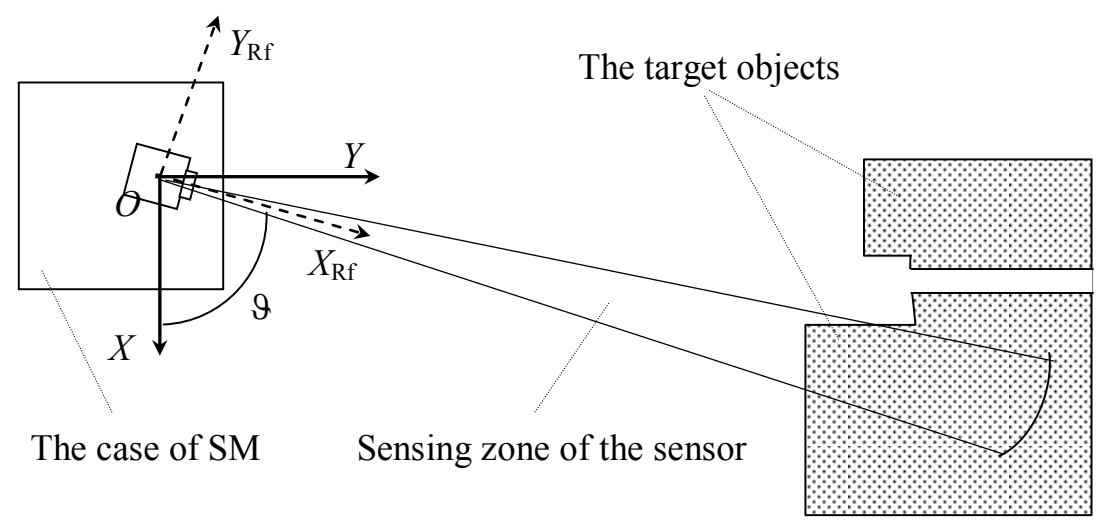

Fig. 4. General scheme of target object scanning process (top view)

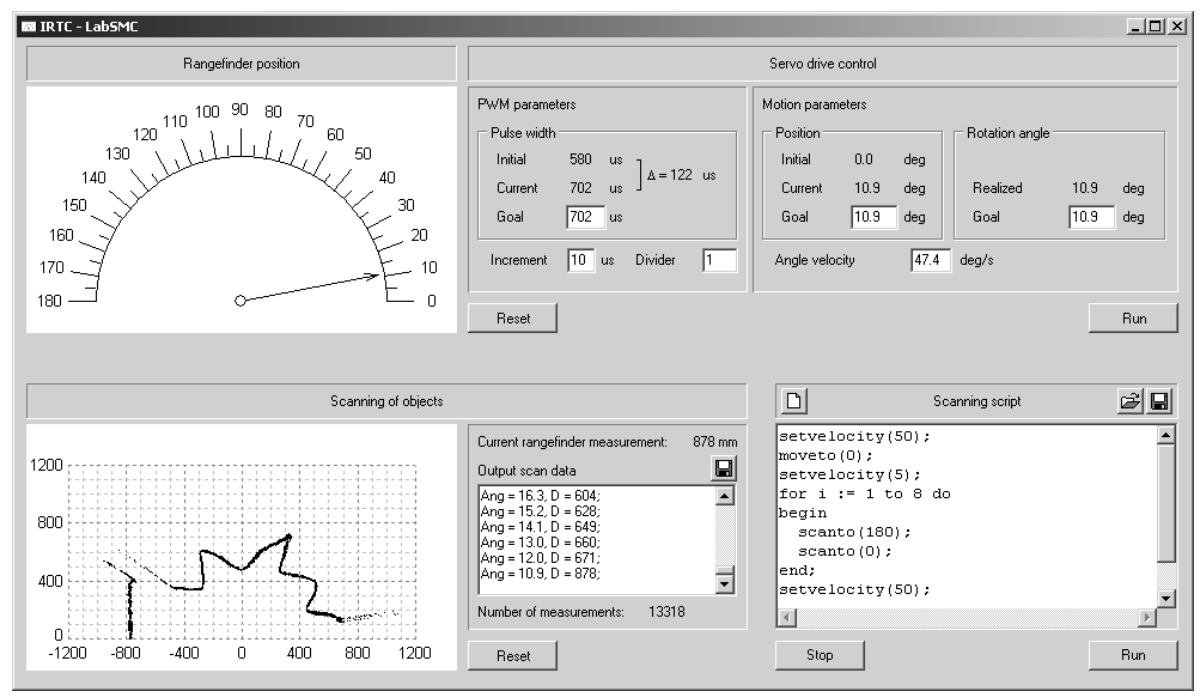

Fig. 5. SM graphic user interface

The angle $\vartheta$ between $O X$ and $O_{\mathrm{Rf}} X_{\mathrm{Rf}}$ axes changes when the servo drive rotates together the sensor case. So the current sensor position is determined by one parameter $\vartheta$ which value is in the range $0^{\circ}-180^{\circ}$. Each rangefinder signal value corresponds to the specific value of angle $\vartheta$. During the scanning process the set of pairs of values (angle $\vartheta$ and distance to the object) are formed.

The graphic user interface of the SM control program is shown in Fig. 5. The user should create a script program that determines the scan mode and range (bottom right in Fig. 5). The scan results forms the array of pairs (angle, distance) (center bottom in Fig. 5) which can be stored on the user's computer for further research. At the bottom left of the Fig. 5, there is a place for real-time graphic display of scan results.

The general scheme of interaction between equipments of our laboratory complex is shown in Fig. 6. 


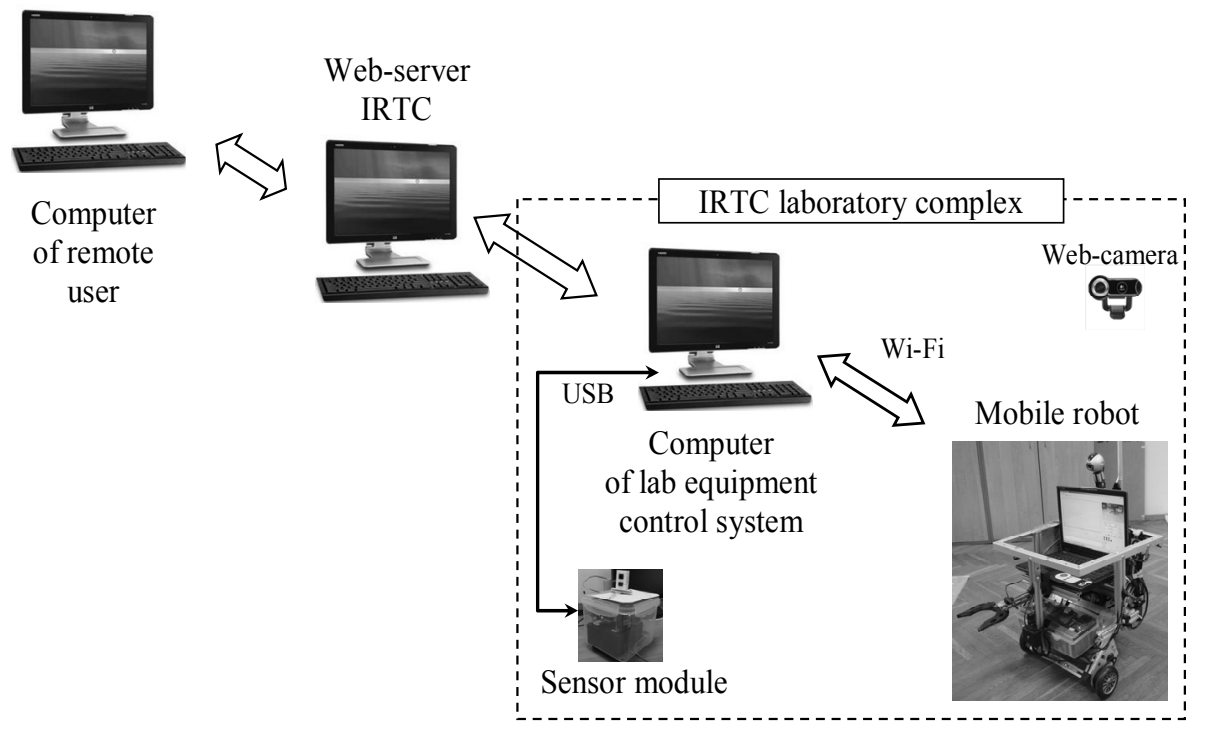

Fig. 6. The scheme of IRTC laboratory complex

\section{THE VIRTUAL COMPONENTS OF LABORATORY COMPLEX}

Practical research is an important form of training processes, but it is critical to update methodological and equipment base of research and educational institutions in time. Even if the institution has sufficient material resources, the laboratory equipment that is needed for modern and actual research in robotics or informational technologies is impossible to purchase due to its lack of sale.

However, now computer resources and communication technologies make it possible to significantly change the methodology of practical research for training and to increase the dynamics of updating of the laboratory base. Let's call the main approaches:

- creation of specialized software that generate virtual images of certain physical systems or processes and simulates their functional properties;

- organization of remote use of laboratory equipment as hardwaresoftware technical systems or their components.

Today, only the virtual laboratory recourses are the popular alternative to hardwaresoftware equipment with remote access. The use of simulation software for such fastgrowing knowledge-intensive areas as autonomous robotics and intelligent information technologies is particularly reasonable. For training purposes the most popular is simulation software executed as web applications by standard Internet browser. Such applications do not require installation on users' computers and can be simultaneously used by an unlimited number of students at any time.

Web applications we developed use 3D modeling, which increases the effect of representing the real technical systems or their components and often eliminates the need of the direct access to lab equipment for a number of practical tasks.

As an example, let us show several web applications for performing certain practical tasks on robotics with automatic checking the results. Appropriate methodical instructions are downloaded from the website for each lab task where the problem statement and all necessary conditions for its implementation are described. 


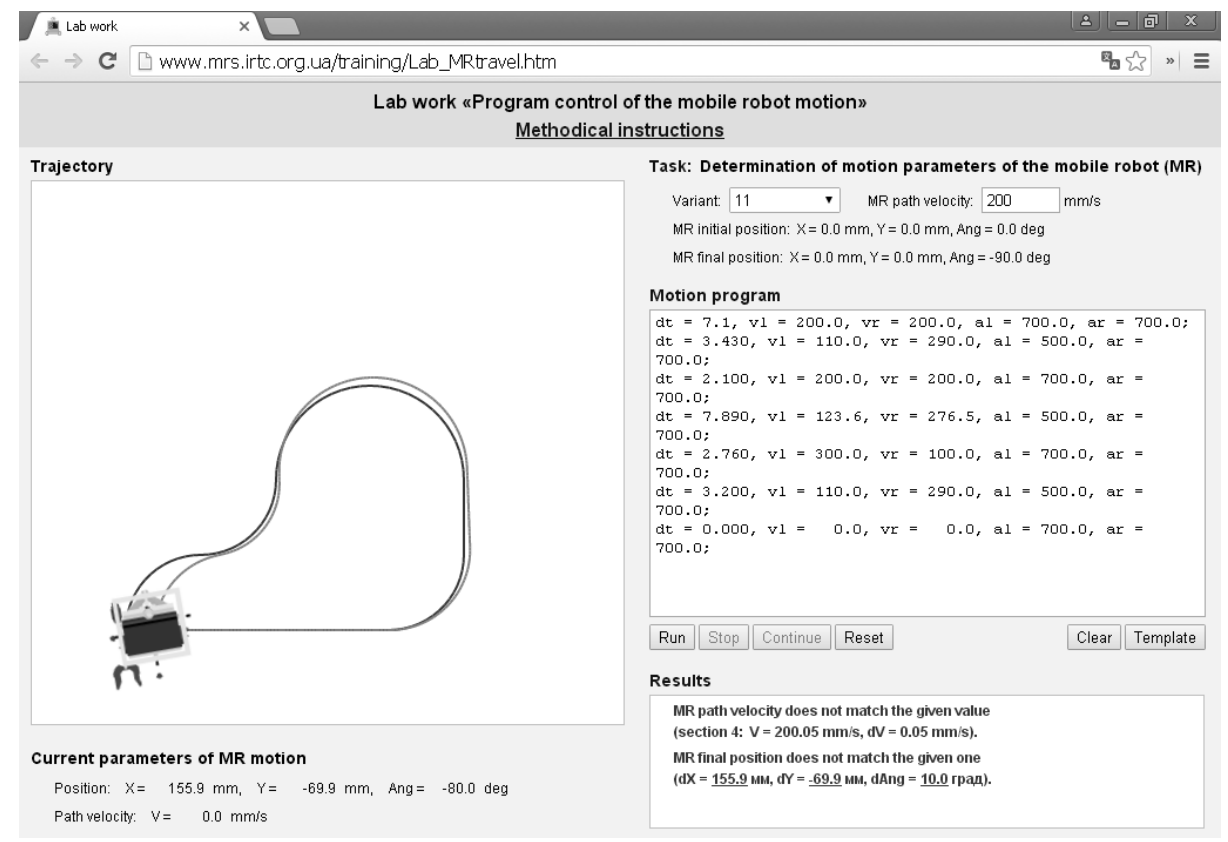

Fig. 7. Web-application for the practical task on the program control of MR

One of the practical tasks focuses on checking theoretical knowledge on automatic control that allows to calculate the parameters of two-wheels MR motion on a horizontal plane along a trajectory of a specified shape with a given constant velocity. The web page for this task after checking the calculated motion parameters is shown in Fig. 7. Here, the trajectory of the red color is specified by the conditions of the task, and blue trajectory corresponds to the executed motion program. At the result box we can see two types of mistakes MR velocity along the trajectory differs from the given one and robot final position does not match the given one. This web-application allows to correct directly the motion parameters and to get satisfactory task solution.

Another practical task is concerned with the base autonomous robotics problem - robot self localization by visual landmarks of a special kind. Webapplication "The virtual environment for determining the position of mobile robot by visual landmarks" allows one to get familiarized with the spatial model of the robot, to obtain the images from its on-board camera as input data for solving of this task with further automated verification of the results of determining the robot position relative to current visual landmarks. All parameters about on-board camera, its position relative to the coordinate system associated with the robot platform and parameters of artificial visual landmarks are described in detail in the methodical instructions that are downloaded from the web-page. The Fig. 8 shows successfully determined coordinates of robot position, in which the on-board camera perceives the given visual landmark properly. 


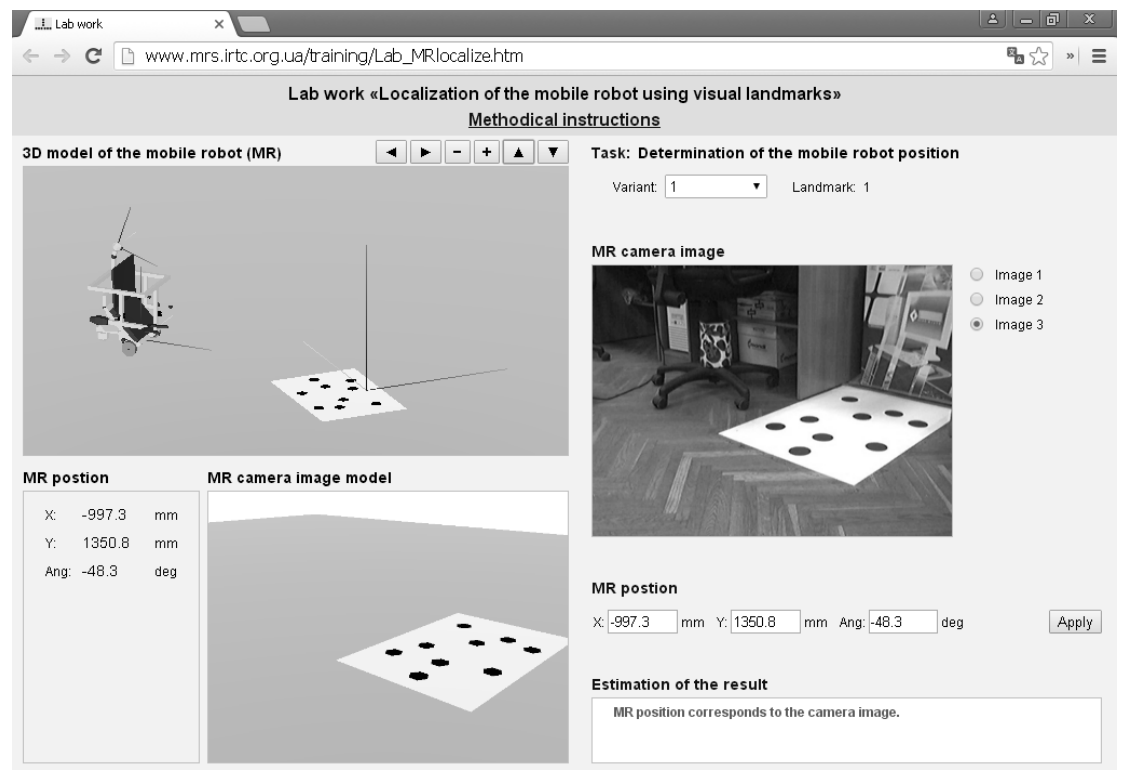

Fig. 8. Web-application for the practical task on determination of MR position

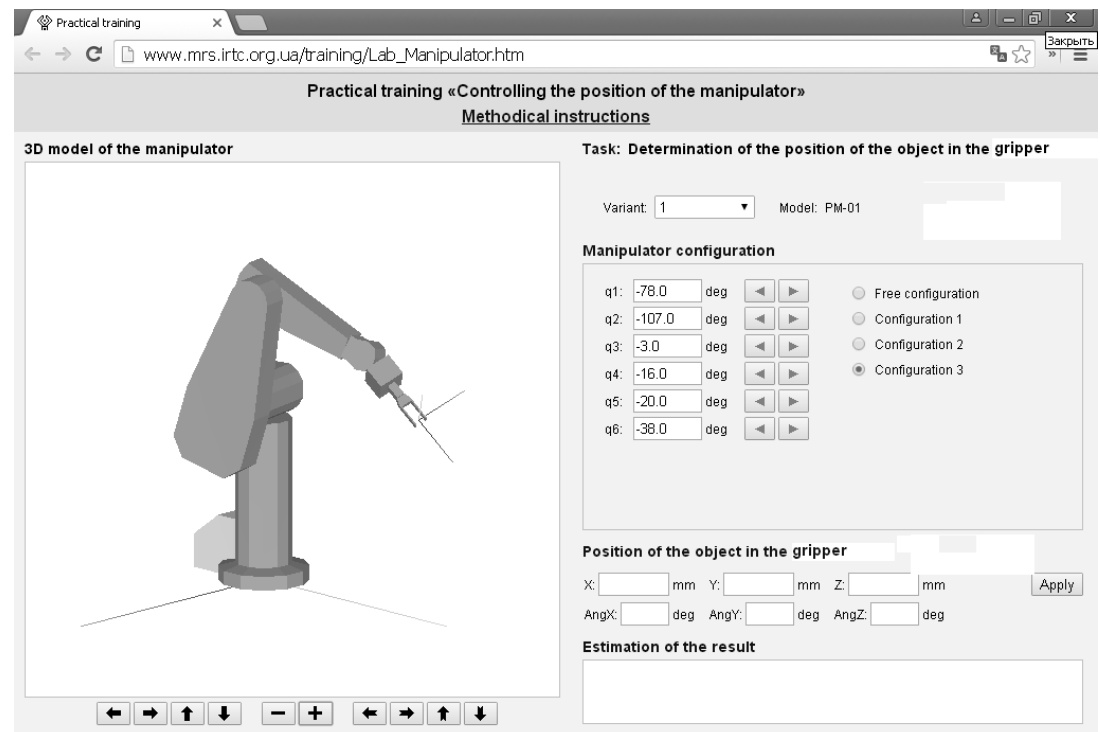

Fig. 9. Web-application for the practical task on controlling the manipulator position

It is practically important to be able to determine the positions of the gripping device of the multi-link manipulator relative to the Cartesian fixed coordinate system when the generalized coordinates of its links are known (direct kinematics problem by position). Web-application "The virtual environment for manipulator position control" helps one to get familiarized with the spatial models of multi-link manipulators of several types, to understand the kinematic connections of the movements of individual links and the principle of controlling 
the position of the gripper. The interrelation of the movements of complex multilink mechanisms is difficult to imagine without computer simulation. This webapplication essentially simplifies the observation of various spatial configurations of manipulators with six degree of freedom in arbitrary viewpoints. Fig. 9 shows the example of input data for practical training on solving task of determining the spatial coordinates of the object if it is in the gripper of manipulator of specific type at the given configuration.

\section{CONCLUSIONS}

Today, leading research teams and corresponding departments of the largest microelectronic industry firms are developing and producing robots of various types and functionalities. A special class of high-tech products has appeared - service robots, which are already widely used in medicine, agriculture, service sector and trade, in logistics and transport, in security and safety services, etc. This situation causes the increase in demand for qualified specialists in the design, maintenance and operation of modern robotic systems and, accordingly, the increase in requirements for the training of such specialists in technical universities.

The importance of having modern means for laboratory and practical training on intelligent information technologies, control systems and robotics was discussed as the issues of preparing future scientists and engineers for the XXI century challenges at the World Congress on Automatic Control of the IFAC-2017 [9].

This article presents the technology of organizing modern and rapidly updated means for practical laboratory research for educational purposes, both with remote use of physical equipment and with the web technology for computer simulation of the behavior of robots or their functional modules. Our laboratory complex with the corresponding techniques is successfully applied for practical training on discipline "Intelligent robots and robotic systems" in the master's degree at the Institute for Applied System Analysis of National Technical University of Ukraine "Igor Sikorsky Kyiv Polytechnic Institute" [10].

\section{REFERENCES}

1. Guimarães E., Maffeis A., Pereira J., Russo B., Cardozo E., Bergerman M. REAL: A virtual laboratory for mobile robot experiments. IEEE Transactions on Education. 2003. Vol. 46. No. 1. P. 37-42.

2. Trukhin A.V. Ispol'zovanie virtual'nykh laboratoriy $\mathrm{v}$ obrazovanii, Otkrytoe $i$ distantsionnoe obrazovanie. 2002. № 4 (8). P. 67-69.

3. Tzafestas C.S., Palaiologou N. Virtual and remote robotic laboratory: comparative experimental evaluation. IEEE Transactions on Education. 2006. Vol. 49. No. 3. P. 360-369.

4. Chaos D., Chac'on J., Lopez-Orozco J.A., Dormido S. Virtual and remote robotic laboratory using EJS. MATLAB and LabVIEW. Sensors. 2013. No. 13. P. 2595-2612.

5. Candelas F.A., Puente S.T., Torres F., Ortiz F.G., GIL P. Pomares J. A Virtual Laboratory for Teaching Robotics. International Journal of Engineering Education. 2003. Vol. 19. No. 3. P. 363-370.

6. Sukhoruchkina O.N. The structures and information processes of mobile robot intelligent control. Zbirnyk naukovykh prats Instytutu problem modelyuvannya v energetytsi im. G.Ye. Pukhova NAN Ukrainy. Kyiv, 2012. No. 62. P. 93-101.

7. Sukhoruchkina O.N., Progonnyi N.V. The intelligent mobile robot - laboratory complex with remote access. Materialy konferentsii "Avtomatyka-2011". (28-30 of Sept, 2011, Lviv). Lviv, 2011. P. 413-414. 
8. Sukhoruchkina O.N., Progonnyi N.V., Voronov M.A. Interpretation and use of the rangefinder measurements in the autonomous mobile robot control problems. USiM. 2017. No. 1. P. 26-34.

9. Website of the World Congress on Automatic Control IFAC-2017. URL: https://www.ifac2017.org/demonstrators/ (Last accessed: 26.12.2018)

10. Sukhoruchkina O.N., Progonnyi N.V. The information technology of intelligent control of mobile robot and their use for training purposes. Materialy 19-i Mizhnar. naukovo-techn. konfer. „Systemnyi analiz ta informatsiyni technologii” SAIT-2017 (22-25 $5^{\text {th }}$ of May, 2017, Kyiv). Kyiv, 2017. P. 325-326.

\section{ЛИТЕРАТУРА}

Resieved 29.11.2018

1. Guimarães E., Maffeis A., Pereira J., Russo B., Cardozo E., Bergerman M. REAL: A virtual laboratory for mobile robot experiments, IEEE Transactions on Education. 2003. 46, No. 1. P. 37-42.

2. Trukhin A.V. Ispol'zovanie virtual'nykh laboratoriy $\mathrm{v}$ obrazovanii, Otkrytoe $i$ distantsionnoe obrazovanie. 2002, № 4 (8), pp. 67-69.

3. Tzafestas C.S., Palaiologou N. Virtual and remote robotic laboratory: comparative experimental evaluation, IEEE Transactions on Education. 2006. 49, No. 3. P. 360-369.

4. Chaos D., Chac' on J., Lopez-Orozco J.A., Dormido S. Virtual and remote robotic laboratory using EJS, MATLAB and LabVIEW, Sensors. 2013. No. 13. P. 2595-2612.

5. Candelas F.A., Puente S.T., Torres F., Ortiz F.G., GIL P. Pomares J. A Virtual Laboratory for Teaching Robotics, International Journal of Engineering Education. 2003. 19, No. 3, pp. 363-370.

6. Сухоручкина О.Н. Структуры и информационные процессы интеллектуального управления мобильным роботом, Збірник наук. праџь Інституту проблем моделювання в енергетиці ім. Г.С. Пухова НАН Украӥни. Київ, 2012. Вип. 62. С. 93-101.

7. Сухоручкина О.Н., Прогонный Н.В. Интеллектуальный мобильный робот - лабораторный комплекс удаленного доступа. Матеріали конф. „Автоматика - 2011”, 28-30 вересня 2011 р., Львів, Україна. Львів: Видавництво Львівської політехніки. 2011. C. $413-414$.

8. Сухоручкина О.Н., Прогонный Н.В., Воронов М.А. Интерпретация и использование измерений сенсора-дальномера в задачах управления автономным мобильным роботом, УСuМ, 2017. № 1. С. 26-34.

9. Сайт всесвітнього конгресу 3 автоматичного керування IFAC-2017. https://www.ifac2017.org/ (Last accessed: 26.12.2018)

10. Сухоручкина О.Н., Прогонный Н.В. Информационные технологии интеллектуального управления мобильным роботом и их использование в учебных целях. Матеріали 19-ї Міжнар. наук.-техн. конф. „Системний аналіз та інформачійні технологіï” SAIT-2017, Київ, 22-25 травня, 2017 р. К.: ННК «ПСА» НТУУ «КПІ» ім. Ігоря Сікорського, 2017. С. 325-326.

Получено 29.11.2018 
Сухоручкіна О.М., старш. наук. співроб., відд. системних інформаційних технологій e-mail: sukhoru@irtc.org.ua Прогонний М.В., наук. співроб., відд. системних інформаційних технологій e-mail: progonny@gmail.com

Міжнародний науково-навчальний центр інформаційних технологій та систем НАН України та МОН України просп. Акад. Глушкова, 40, Київ, 03187, Україна

\section{ІНФОРМАЦІЙНА ТЕХНОЛОГІЯ ДЛЯ ДИСТАНЦІЙНИХ

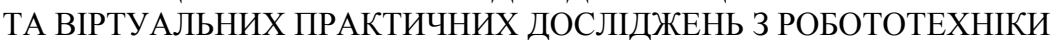

Bcmyn. Розглянуто проблему своєчасного оновлення лабораторних засобів для досліджень і навчання з робототехніки та інтелектуальних технологій. Запропоновано інформаційну технологію організації лабораторного комплексу 3 двома типами компонентів - дистанційно керованого робототехнічного обладнання та віртуальних засобів для проведення відповідних практичних досліджень. Сьогодні саме такі підходи стають найоптимальнішими для забезпечення дослідницьких та навчальних процесів сучасними ресурсами набуття практичного досвіду за науковими напрямками, які швидко розвиваються.

Метою статті $€$ аналіз можливостей інформаційних технологій в організації віддаленого доступу до фізичного обладнання та віртуальних засобів для практичних досліджень і навчання з робототехніки.

Методи. Використано методики розподілених інформаційних та обчислювальних процесів, комунікаційні протоколи та програмування веб-застосунків.

Результати. Розглянуто два типи спеціалізованих засобів нашого лабораторного комплексу - фізичне обладнання 3 дистанційним доступом та віртуальні середовища. Наведено загальні структури обладнання, що складається з автономного мобільного робота i сенсорного модуля, які можуть використовуватися дистанційно для певних досліджень і практичних занять. Показано деякі приклади веб-застосунків, які призначено для ознайомлення з певними видами робототехнічних систем за ї $3 \mathrm{D}$ моделями та виконання відповідних практичних завдань з автоматичною перевіркою результатів.

Висновки. Використання компонентів лабораторного комплексу за створеною технологією приводить до своєчасного поширення ресурсів проведення на сучасному рівні досліджень та відповідних практичних робіт навчального характеру 3 робототехніки та інтелектуальних технологій студентами багатьох технічних університетів України.

Ключові слова: робототехніка, технології дистанційного керування, віртуальна лабораторія, веб-застосунки. 
Сухоручкина О.Н., старш. науч. сотр.,

отд. системных информационных технологий

e-mail: sukhoru@irtc.org.ua

Прогонный Н.В., науч. сотр.,

отд. системных информационных технологий

e-mail: progonny@gmail.com

Международный научно-учебный центр информационных технологий

и систем НАН Украины и МОН Украины

просп. Акад. Глушкова, 40, Киев, 03187, Украина

\section{ИНФОРМАЦИОННАЯ ТЕХНОЛОГИЯ ДЛЯ ДИСТАНЦИОННЫХ И ВИРТУАЛЬНЫХ ПРАКТИЧЕСКИХ ИССЛЕДОВАНИЙ ПО РОБОТОТЕХНИКЕ}

Рассмотрена проблема своевременного обновления лабораторных средств для обучения и исследований по робототехнике и интеллектуальным информационным технологиям. Предложена технология организации лабораторного комплекса с двумя типами компонентов - программно-аппаратное оборудование с дистанционным управлением и программные веб-приложения для практических занятий в виртуальной среде. Приведено общее структурное описание действующего оборудования в виде мобильного робота и сенсорного модуля. Показано несколько примеров вебприложений, позволяющих ознакомиться с пространственными моделями определенных видов робототехнических систем и выполнить конкретные практические задания с возможностью автоматической проверки полученного результата.

Ключевые слова: робототехника, технологии дистанционного управления, виртуальная лаборатория, веб-приложения. 